\title{
Methods for reducing low emissions from heating devices in single- family housing
}

\author{
Danuta Proszak- Miąsik ${ }^{1, *}$, Stawomir Rabczak ${ }^{2}$, \\ 1,2 Rzeszow University of Technology, al. Powstańców Warszawy 12, 35-959 Rzeszów, Poland
}

\begin{abstract}
By low emission, we mean the pollution of the lower troposphere from emitters not exceeding $50 \mathrm{~m}$ in height and most often located at a level of $10 \mathrm{~m}$ in height. Due to such emitters the altitude this pollution accumulates around is its place of emission. The basic source of low emissions in Poland are pollutants caused by vehicular traffic and during the process of burning low quality coal, and rubbish - in domestic furnaces. The reason is the lack of proper filtrtation in these devices. Most air pollutants are gaseous substances. The second group is dust. Contamination is different in physical and chemical terms. The most dangerous for people and the environment are: dioxins, polycyclic aromatic hydrocarbons (benzopyrene), carbon monoxide, sulfur dioxide, nitrogen oxides, heavy metals (eg cadmium, manganese, chromium), and hydrogen cyanide. The largest increase in suspended particulates during the heating season affects a majority of single-family housing estates, due to the lack of system heat. It is a fact that many users have antiquated coal furnaces in which low-quality coal and sometimes waste is burned, for example, colored press, rubber, plastics, and impregnated wood. Unfavorable weather conditions during the heating season intensify this phenomenon which is known as smog. This publication is aimed at presenting methods for reducing the emission of pollutants into the air due to the combustion of inadequate fuel in areas of low residential buildings. The solutions, based on the replacement of fifth-generation furnaces as well as a change of fuel, have been proposed.
\end{abstract}

\section{Introduction}

Air pollution is the most dangerous form of environmental poisoning due to its direct impact on all living organisms, the coverage of large areas and the ease of movement of pollutants. That is why air protection is one of the priority directions of every province.

Every type of human activity, in particular the production of energy and heat, road transport and agriculture, causes the emission of pollutants into the air. Industrial institutions are obliged to install air-purifying devices such as, for example, chimney filters, the use of catalysts in vehicles, or the use of sulfur-free and unleaded fuels. However, the problem is the reduction of emissions from local boiler rooms and individual furnaces

\footnotetext{
*Corresponding author: dproszak@prz.edu.pl
} 
without exhaust purification devices. Clusters of this type of equipment occur, inter alia, in the area of single-family housing, where the height of emitters does not exceed $40 \mathrm{~m}$, and the phenomenon of emissions below this level is colloquially called low emission. This publication analyzes the methods of reducing this type of emissions using the example of a single-family housing estate.

The problem of low emission pollution affects the entire year, while the most unfavorable situation occurs in winter, when there is the greatest demand for thermal energy, when almost every building is equipped with a source of heat which is sometimes obsolete, and the ignorance of people who burn fuel and rubbish in an unsuited quality of device. This phenomenon is also enhanced by atmospheric conditions such as windless weather and high humidity. Therefore, pollutants remain near their place of emission creating an unnatural cloud which we call smog. The areas most threatened are areas located in valleys or other depressions of the area.

The accumulation of pollutants causes inhalation of harmful substances by tenants of housing estates, negatively affecting health and the environment. Seniors, children and adolescents, as well as the chronically ill, pregnant women and smokers are particularly vulnerable to becoming infected as a result of air pollution. They are most often cardiovascular, respiratory and heart diseases. There is an increase in juman mortality and the number of cancer patients. [9]

The most frequent low emission pollutants are:

- suspended flares are small particles floating freely in the air. They may be of a natural origin - for example, mineral dust, sea aerosol, but may also be a product of human activity. This group includes, for example, soot particles that arise in the combustion of coal or other fuels, secondary dust particles that arise as a result of transformations of other pollutants in the air, such as sulfur and nitrogen oxides.

In the air quality analysis, two basic types of particulate matter are distinguished:

PM10, i.e. dust with particle diameters below $10 \mu \mathrm{m}$. It is so small that it penetrates deep into the respiratory system. Part of this dust, with particle diameters between 2.5 and $10 \mu \mathrm{m}$, is referred to as "coarse dust particles". The fraction consists mainly of mineral particles that are lifted from the ground by the wind. Due to the relatively large particle size, thick dust reaches the respiratory system not deeper than into the bronchi.

PM2.5, i.e. fine particles, with particle diameters below $2.5 \mu \mathrm{m}$. On average, it accounts for about $60 \%$ of PM10 dust in the summer season and over $75 \%$ in the cold season. It consists mainly of soot and other products resulting from combustion processes. It causes a high health risk, because due to the small size of the particles it can penetrate into the deepest parts of the respiratory system, into the alveoli and into the bloodstream.

- sulfur dioxide $\left(\mathrm{SO}_{2}\right)$ - is one of the factors which cause the formation of acid rain,

- nitrogen oxides $\left(\mathrm{NO}_{\mathrm{x}}\right)$ are one of the causes of an ozone hole and smog formation,

- heavy metals ( $\mathrm{Hg}$ - mercury, $\mathrm{Cd}$ - cadmium, $\mathrm{Pb}$ - lead, $\mathrm{Mn}$ - manganese, $\mathrm{Cr}$ - chromium) harmful to humans, animals and plants,

- aromatic hydrocarbons (PAH - including $\alpha$-benzopyrene) - carcinogenic and causing severe intoxication,

-dioxins - poisonous chemicals, often responsible for the emergence of cancer or infertility. [6].

\section{The combustion of fuels and the spread of pollutants}

Combustion and pollution formation are closely interrelated processes. Impurities that are introduced into the air depend to a large extent on the type of fuel and combustion technology. 
In the case of single-family housing, coal was the basic energy carrier for a long time due to its price and access. Brown coal, silts and fleets were also burned in mining regions. However, the introduced anti-smog laws in many regions now forbid the burning of these fuels. Currently, some buildings are also heated by gas or system heat.

Substances generated during the combustion of fuels that are subject to mandatory measurement or estimation in Poland are nitrogen oxides, sulfur oxides, suspended dust, lead, carbon black, carbon monoxide, carbon monoxide, and non-volatile and volatile organic compounds.

The contaminants that arise depending on the type of fuel burned are presented in Table 1 below.

Table 1. Pollutants arising from the combustion of fuels [5].

\begin{tabular}{|l|l|l|}
\hline Solid fuels & brown and stone coal & $\begin{array}{l}\text { Sulfur oxides } \mathrm{SO}_{\mathrm{x}}, \text { nitrogen oxides } \mathrm{NO}_{\mathrm{x}}, \\
\text { carbon monoxide } \mathrm{CO}, \mathrm{Carbon} \text { dioxide } \mathrm{CO}_{2}, \\
\text { dust (suspended, benzo ( } \alpha \text { ) pyrene, } \\
\text { methane, ammonia, arsenic, nickel, lead, } \\
\text { zinc and its compounds, copper, cadmium, } \\
\text { benzene mercury, chlorine and its } \\
\text { inorganic compounds }\end{array}$ \\
\hline Liquid fuels & heating oil light & $\begin{array}{l}\text { Non-methane sulfur oxides, methane, } \\
\text { nitrogen oxides } \mathrm{NO}_{\mathrm{x}}, \text { carbon monoxide } \mathrm{CO}, \\
\text { carbon dioxide } \mathrm{CO}_{2},\end{array}$ \\
\hline Gas fuels & natural gas & $\begin{array}{l}\text { Carbon monoxide } \mathrm{CO} \text {, nitrogen oxides } \mathrm{NO}_{\mathrm{x}} \\
\text { dust (suspended), Carbon dioxide } \mathrm{CO}_{2}, \\
\text { methane }\end{array}$ \\
\hline Garbage & $\begin{array}{l}\text { tar, lead and cadmium } \\
\text { dioxins, hydrogen cyanide, PAH, VOCs, } \\
\text { PCCD/PCDF }\end{array}$ \\
\hline
\end{tabular}

The state of air pollution is variable over time and space, this is due to the spread of pollutants. This process is conditioned by the following factors: meteorological, topographic and technical-technological.

The meteorological factors include: atmospheric turbulence, vertical temperature gradient, atmospheric precipitation, thickness of the so-called mixing zone, and horizontal air mass movement. Under topographical factors, there are such issues as, for example: terrain, its sculpture, location of water reservoirs, forests, ground properties and land development. The technical and technological factors include the outlet velocity, the height and diameter of the emitter as well as the temperature of the outgoing gases.

Of all the three factors mentioned, meteorology has the greatest impact on the intensity of the exchange of streaks of pollutants in the atmosphere. Molecular diffusion has the smallest influence on the propagation of mass of substances.

\section{Low emission reduction methods}

\section{a. Thermo-modernization of a building}

By reducing the demand for energy, we reduce fuel consumption and thus the emission of pollutants. You can reduce a house's energy demand by the thermo-modernization of existing buildings or building new ones, eg in an energy-saving or passive system. In order to carry out thermo-modernization, heat insulation of the building elements through which most heat escapes (reduction of heat bridges) and window replacements should be made. The greatest heat losses are usually at the external walls, roof, ceiling and basement. There 
are a lot of different warming materials available, and styrofoam and mineral wool are among the most popular and at the same time the easiest to attach. Thanks to thermomodernization, up to $40 \%$ of energy can be saved during the heating season.

\section{b. Boiler replacement}

Old stoves, which are fired with coal, wood and wood chips, emit the most harmful compounds into the atmosphere, worsening the health of people. This problem can be solved only by connecting houses to the public heating network or by removing old furnaces. Obsolete coal-fired boilers can be replaced with coal-fired boilers of the fifth class of emission parameters. It is also a very good idea to replace the furnace with a gas boiler, oil boiler, gasifying boilers, class 5 wood pellet boilers or eco-pea coal boilers that emit negligible amounts of dust. Figure 1 shows the level of dust emissions from typical domestic heating devices $\left[\mathrm{mg} / \mathrm{m}^{3}\right]$. Also, installations using alternative energy, supporting the production of heat as well as electricity, eg solar panels, photovoltaic cells, wind turbines, heat pumps, are becoming popular. The most ecological solution is the installation of a heat pump that does not emit any pollution in the workplace, but its purchase in Poland is still quite expensive [7].

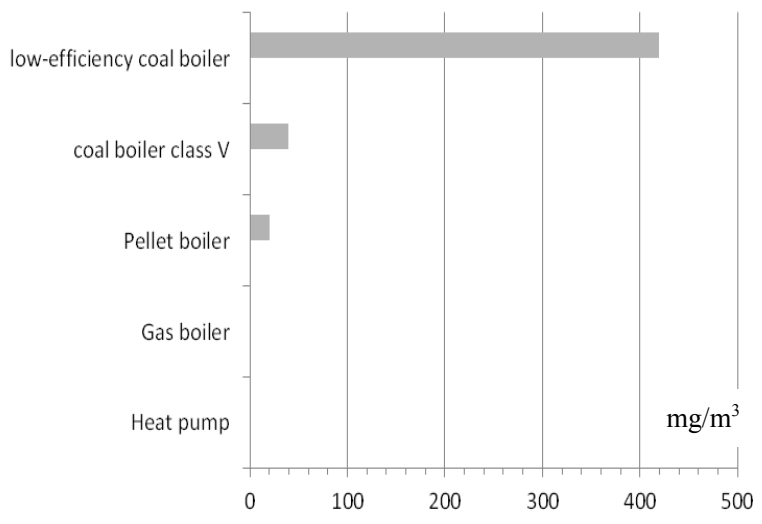

Fig. 1. Dust emissions from domestic heating devices $\left[\mathrm{mg} / \mathrm{m}^{3}\right]$ [4].

Table 2 shows what the benefits will be of replacing the coal-fired boiler with the socalled "trash" for a gas condensing boiler.

Table 2. Change in the level of pollutant emissions when replacing a boiler from coal to gas condensing.

\begin{tabular}{|c|c|}
\hline $\begin{array}{c}\text { saving in heat } \\
\text { consumption }\end{array}$ & $\sim 20000[\mathrm{kWh} /$ year $]$ \\
\hline $\begin{array}{c}\text { reduction of emissions } \\
\mathrm{CO}_{2}\end{array}$ & $\sim 15500[\mathrm{~kg} /$ year $]$ \\
\hline $\begin{array}{c}\text { reduction of emissions } \\
\mathrm{CO}\end{array}$ & $\sim 1000[\mathrm{~kg} /$ year $]$ \\
\hline $\begin{array}{c}\text { reduction of emissions } \\
\text { dust }\end{array}$ & $\sim 27[\mathrm{~kg} /$ year $]$ \\
\hline $\begin{array}{c}\text { reduction of emissions } \\
\mathrm{SO}_{2}\end{array}$ & $\sim 130[\mathrm{~kg} /$ year $]$ \\
\hline $\begin{array}{c}\text { reduction of emissions } \\
\mathrm{NO}_{\mathrm{x}}\end{array}$ & $\sim 15[\mathrm{~kg} /$ year $]$ \\
\hline
\end{tabular}




\section{c. Rubbish burning is prohibited}

Statistics indicate that each person produces about $300 \mathrm{~kg}$ of rubbish per year. These are huge amounts and they are constantly growing. During the autumn-winter heating season homeowners, wanting to get rid of litter, burn them in home heating devices. Garbage is not a kind of fuel, and their calorific value is not great, their burning will also not bring the expected benefits in the form of heating for the house. During their combustion, various kinds of carcinogenic compounds are emitted into the atmosphere, which do not die in the chimney, but fall down and go directly into our lungs, slowly destroying the body. Rubbish is best segregated and recycled. And their combustion should take place in adapted incineration plants, under the supervision of specialized employees. In domestic furnaces, the combustion temperature is around $200-500^{\circ} \mathrm{C}$, and to reduce the formation of harmful substances, it should be around $900^{\circ} \mathrm{C}$. Waste incineration is treated as an offense and is subject to a fine. This offense has been defined in the Waste Act (Article 191) [10,8].

\section{d. Installation of electrostatic precipitators for solid fuel boilers}

One of the ways to reduce low emissions is to install electrostatic precipitators (electrostatic precipitators) for boilers for solid fuels. It is a modern solution that effectively reduces the emission of harmful compounds and dusts. The electrofilter is a small size dedusting device that is installed in the heating system. An electrode is placed inside the electrostatic precipitator, which generates high voltage with low electrical current by causing repulsion on the dust contained in the exhaust. Then, under the influence of the acting electrostatic force, it "deposits" them on the surface of the collecting electrodes. The electrofilter is suitable for boilers with a feeder. Its effectiveness is quite high and ranges from $50-90 \%$ $[10]$.

\section{e. The use of renewable energy sources}

\section{i. Heat Pump}

The heat pump uses renewable energy accumulated in soil, air, groundwater, surface water or solar radiation. It can be used for heating a building, in the summer for cooling it and for preparing hot water throughout the year. The heat pump is supplied with electricity which is taken from the grid or from other alternative sources.

\section{ii. $\quad$ Solar collectors}

Solar collectors and photovoltaic cells are devices that allow for the free acquisition of heat and electricity from the energy of the sun (sun's rays). Their installation in a household allows you to reduce the consumption of fossil fuels. Solar collectors in favorable weather conditions can cover $100 \%$ of the demand for hot water in the summer season [5]. In the winter season, the water is heated using other sources. Appropriate automation helps to maximize the energy of the sun throughout the year [3].

\section{f. Increasing green areas}

Plants filter the air very well. They perform a function, not only aesthetic, but also absorb carbon monoxide, poisonous substances, and oxygenate the air we breathe. Each plant has a different structure, which is why they have different filtration abilities. 
In the city near roads, squares or parks you can also plant shrubs and trees to help fight smog. Trees are effective in neutralizing pollutants. Coniferous plants perform well in winter, because their needles are usually covered with wax, to which dust particles stick. However, coniferous plants may die due to impurities. They are less resistant than deciduous plants. One hectare of deciduous forest can produce about $700 \mathrm{~kg}$ of oxygen, which is the daily need for oxygen for over 2500 people.

Green roofs are becoming more and more common on housing estates, which are supposed to support the fight against smog. Vegetation planted on roofs significantly improves the condition of the air, mitigating the emerging smog pollution. Gardens at heights filter the air, reduce pollution and contribute to the production of oxygen. These are not the only advantages of green roofs. Their creation also brings other benefits. They are a good insulator, protecting against building heating in the summer and chilling in winter. This type of roof is resistant to all mechanical damage and wind. It improves the aesthetics of the city landscape, where there is no naturally growing greenery. The green roof also retains a part of the water, which collects from atmospheric precipitation, so less water gets into the sewerage system.

\section{Comparison of pollutants emission from domestic heat sources}

The aim of the analysis is to compare the amount of pollutants emitted by different heat sources that can be used to heat single-family houses and prepare hot water.

The analysis was carried out for a building with a heating area of $150 \mathrm{~m}^{2} .2$ variants of heat demand were adopted when the building is poorly insulated and the demand is 140 $\mathrm{kWh} / \mathrm{m}^{2}$ year; and the second when the building has undergone thermo-modernization and the heat demand is $90 \mathrm{kWh} / \mathrm{m}^{2}$ year.

The consumption of hot water in the amount of 3001/day, and the temperature of the medium of $45^{\circ} \mathrm{C}$ were adopted.

As a source of heat, a coal boiler was adopted and then it was replaced with a gas boiler, a pellet boiler, and an additional heat source - solar collectors - was introduced.

The calculation of the emission volume was made on the basis of the emission factor for chemical energy introduced in the fuel, which is equal to:

$$
E=B W_{o} W
$$

where: B - fuel consumption, $\mathrm{W}$ - emission factor per megajoule of chemical energy contained in fuel, Wo - the calorific value of fuel.

Fuel heating values were adopted: natural gas $10.29 \mathrm{kWh} / \mathrm{m}^{3}$, liquid gas $25.6 \mathrm{kWh} / \mathrm{m}^{3}$, fuel oil $10.09 \mathrm{kWh} / \mathrm{dm}^{3}$, coal $5.83 \mathrm{kWh} / \mathrm{kg}$, eco- pea coal $6.94 \mathrm{kWh} / \mathrm{kg}, 5.36 \mathrm{kWh} / \mathrm{kg}$ pellet. The emission factor for the megajoules of chemical energy contained in the fuel was adopted on the basis of tables with emission factors [1]. Table 3 shows the results. 
Table 3. Summary of annual emissions.

\begin{tabular}{|c|c|c|c|c|c|c|c|}
\hline Fuels & Boiler type & Variant & $\begin{array}{c}\mathrm{CO}_{2} \\
\mathrm{~kg} / \text { year }\end{array}$ & $\begin{array}{c}\mathrm{CO} \\
\mathrm{kg} / \text { year }\end{array}$ & $\begin{array}{c}\text { dust } \\
\mathrm{kg} / \text { year }\end{array}$ & $\begin{array}{c}\mathrm{SO}_{2} \\
\mathrm{~kg} / \text { year }\end{array}$ & $\begin{array}{c}\mathrm{NO}_{\mathrm{x}} \\
\mathrm{kg} / \text { year }\end{array}$ \\
\hline \multirow{6}{*}{ Natural gas } & \multirow{2}{*}{$\begin{array}{c}\text { old type boiler, } \\
\text { constant } \\
\text { temperature }\end{array}$} & I & 7573 & 4.5 & 0.01 & 0.12 & 3.28 \\
\hline & & II & 5332 & 3.1 & 0.01 & 0.08 & 2.31 \\
\hline & \multirow{2}{*}{$\begin{array}{l}\text { condensing } \\
\text { boiler }\end{array}$} & I & 5932 & 3.5 & 0.01 & 0.09 & 2.57 \\
\hline & & II & 4184 & 2.5 & 0.01 & 0.07 & 1.81 \\
\hline & \multirow{2}{*}{$\begin{array}{c}\text { condensing } \\
\text { boiler }+ \text { solar } \\
\text { collectors }\end{array}$} & I & 5309 & 3.1 & 0.01 & 0.08 & 2.3 \\
\hline & & II & 3561 & 2.1 & 0.01 & 0.06 & 1.54 \\
\hline \multirow{4}{*}{ Stone coal } & \multirow{2}{*}{$\begin{array}{c}\text { low-efficiency } \\
\text { coal boiler }\end{array}$} & I & 18349 & 755.5 & 18.85 & 103.62 & 15.11 \\
\hline & & II & 13036 & 536.8 & 13.47 & 73.62 & 10.74 \\
\hline & \multirow{2}{*}{$\begin{array}{l}\text { boiler for eco- } \\
\text { pea coal }\end{array}$} & I & 15374 & 633.0 & 15.78 & 86.82 & 12.66 \\
\hline & & II & 11124 & 458.0 & 11.49 & 62.82 & 9.16 \\
\hline \multirow{2}{*}{ Pellets } & pellet boiler & I & 2109 & 62.5 & 0.55 & 6.39 & 6.18 \\
\hline & & II & 1504 & 44.6 & 0.32 & 4.55 & 4.41 \\
\hline \multirow{7}{*}{ Heating oil } & \multirow{2}{*}{$\begin{array}{c}\text { low } \\
\text { temperature } \\
\text { boiler }\end{array}$} & I & 9445 & 5.5 & 0.21 & 19.1 & 6.74 \\
\hline & & II & 6735 & 4.0 & 0.15 & 13.62 & 4.81 \\
\hline & \multirow{2}{*}{$\begin{array}{l}\text { condensing } \\
\text { boiler }\end{array}$} & I & 7728 & 4.5 & 0.17 & 15.63 & 5.52 \\
\hline & & II & 5457 & 3.3 & 0.12 & 11.03 & 3.9 \\
\hline & \multirow{2}{*}{$\begin{array}{c}\text { condensing } \\
\text { boiler }+ \text { solar } \\
\text { collectors }\end{array}$} & I & 6907 & 4.0 & 0.15 & 13.97 & 4.93 \\
\hline & & II & 4636 & 2.9 & 0.1 & 9.37 & 3.31 \\
\hline & heat pump & & - & - & - & - & - \\
\hline
\end{tabular}

The calculations are estimated for specific assumptions. The approximate values of efficiency were assumed. It should be remembered that the efficiency of heating domestic water for boilers for solid fuels is significantly reduced outside the heating season, when there are increased starting and parking losses of the boiler with increased boiler water capacity and the weight of the boiler body.

Analyzing the results, it can be seen that the greatest benefits are obtained by exchanging coal-fired boilers for gas condensing boilers or heat pumps.

In the case of electricity (heaters, electric heaters, heat pumps) - pollutant emissions are not determined because they do not cause such emissions locally in the place of installation. Emissions for this type of heat sources are generated by power plants or combined heat and power plants that are equipped with advanced combustion and flue gas cleaning technologies. In addition, you can equip the building with photovoltaic systems that will also produce clean electricity.

\section{Conclusions}

In 2015, the President of the Republic of Poland,Andrzej Duda signed the so-called antismog bill which provides that the voivodeship assembly will be able, by way of a resolution being an act of local law, to introduce restrictions or prohibitions regarding the operation of installations and equipment in which a combustion process takes place in order to prevent negative impacts on the environment or monuments. This is to help local governments to 
limit the negative impact of pollutant emissions from old, ineffective heating devices. As a consequence, pollution and air quality should be improved.

In order for the reduction of low emissions to bring the expected improvement in air quality, it must be made by precisely and completely counteracting this phenomenon. Undoubtedly, the leading factor in the deepening of low emissions is inefficient burning of fossil fuels and garbage in domestic boiler rooms, by people with a low knowledge of ecology. The simplest action to counteract this phenomenon is to replace obsolete coal-fired boilers with those that are fired with gas, thus emitting less harmful dust and compounds. That is why an important role is played by increasing ecological awareness among the public, manifesting itself in care for the state of the environment. An important role here is played by the framework programs for financing this type of investment.

\section{References}

1. KOBiZE, “Emission factors for fuel combustion”, IOŚ-BIP, 2015

2. K. Nowak, M. Bukowska, D. Proszak- Miąsik, S. Rabczak, "Emission of Air Pollutants in the Hot Water Production", Iop Conf Ser-Mat Sci., 245, (2017)

3. D. Proszak-Miąsik, S. Rabczak, "Impact of solar radiation change on the collector efficiently", Journal of Ecological Engineering, vol. 18, issue 1, pp. 268-27, (2016)

4. EMEP/EEA air pollutant emission inventory guidebook "Combustion in energy and transformation industries", https:/www.eea.europa.eu/publications/emep-eeaemission-inventory-guidebook-2009, (2009)

5. D. Proszak-Miąsik, M. Bukowska, K. Nowak, S. Rabczak, „Astronomical and Meteorological Conditions of a Solar System Operation", IOP Conference Series: Materials Science and Engineering, z.245(2017)

6. WIOŚ Warszawa, "Characteristics of monitored substances", http://sojp.wios.warszawa.pl (online 04. 2018)

7. W. M. Lewandowski, M. Ryms, „Biofuels. Pro-ecological renewable energy sources”, WNT, Warszawa, 2013,

8. https://www.lexlege.pl/ustawa-o-odpadach/art-191/

9. J. Jędrak, "Wpływ zanieczyszczeń powietrza na zdrowie”, Krakowski Alarm Smogowy

10. J. W. Pałasz, "Niska emisja ze spalania węgla $i$ metody jej ograniczenia", Wydawnictwo Politechniki Śląskiej, Gliwice, 2016 